\title{
The effect of financial performance, IOS, and firm size on cash holdings: the role of dividend policy as moderating variable
}

\author{
Woen Cliff Wibowo ${ }^{1}$ and Sugeng Wahyudi2 \\ 1,2Department of Management, Faculty of Economics and Business, Universitas Diponegoro, Indonesia
}

\begin{abstract}
This study aims to determine and analyze the effect of financial performance (profitability, leverage, capital expenditure, liquid asset substitute), IOS, and company size on cash holding by using dividend policy as a moderating variable. The number of samples of this study was 108 observations of non-financial companies in the LQ 45 Index for the period of 2011-2016. The results of moderated regression analysis (MRA) shows that profitability has a positive effect on cash holding, while leverage, liquid asset substitute, IOS, and firm size have negative effect on cash holdings. The results of this study also show that dividend policy can be a moderating variable which weakens the positive effect of profitability on cash holding and strengthens the negative effect of capital expenditure, but the dividend policy is not able to moderate the influence of leverage on cash holding. As a result, the companies were able to make large dividend payouts to reduce the excessive amount of cash holding that managers often abused for their own benefits and increasingly prospering investors with a given dividend.
\end{abstract}

cash holding; profitability; leverage; capital expenditure; liquid asset substitute; IOS; firm size; dividend policy

\section{INTRODUCTION}

Cash is a major asset for business. Without the availability of cash, a company is unable to carry out its core activities such as operating, investing and financing. Cash Holding is the company's decision to determine how much cash and cash equivalents that it needs to possess in order to support the company's business activities. trade off theory advises companies to optimize cash holding by comparing the additional costs and benefits gained by cash holding (Keynes, 1936)

There are a lot of factors affecting cash holding such as profitability (ROE), leverage (DAR), liquid asset substitute (NWC), capital expenditure (CAPEX), investment opportunity set (IOS), company size and dividend policy (Drobetz \& Gruningen, 2007; Bates et al., 2009; Kim et al., 2011; Al-Najjar, 2013; and Yang et al., 2017)

This research was conducted because of the business phenomenon showed inconsistency of the data fluctuation (in increasing and decreasing) of cash holding $(\mathrm{CH})$ variable value with other variables (ROE, DAR, NWC, CAPEX, SIZE, IOS, and DPR). Table 1 shows the differences in the results on the factors affecting cash holding and business phenomenon of non-conformity increase or decrease in value of cash holding by increasing or decreasing profitability, leverage, capital expenditure, liquid asset substitute, investment opportunity set, company size and dividend policy have made it necessary for doing a re-research related to these variables.

Some previous studies also shown inconsistent results regarding the effect of profitability on cash holding. The research of Ogundipe et al (2012) showed profitability had a positive effect on cash holding, while Al-Najjar (2013) showed profitability had negative effect on cash holding, and Mesfin (2016) study showed profitability had no significant effect on cash holding. 
Table 1.

The Average of Non-Financial Enterprise Variables in the LQ 45 Index

\begin{tabular}{lllllll}
\hline Variable & $\mathbf{2 0 1 1}$ & $\mathbf{2 0 1 2}$ & $\mathbf{2 0 1 3}$ & $\mathbf{2 0 1 4}$ & $\mathbf{2 0 1 5}$ & $\mathbf{2 0 1 6}$ \\
\hline Cshhold (x) & 0.181 & 0.165 & 0.147 & 0.140 & 0.139 & 0.145 \\
Growth (\%) & & -8.79 & -11.21 & -4.82 & -0.21 & 3.76 \\
DAR (x) & 0.386 & 0.450 & 0.452 & 0.493 & 0.235 & 0.227 \\
Growth (\%) & & 16.78 & 0.42 & 8.95 & -5.04 & -8.77 \\
ROE (x) & \multirow{2}{*}{0.255} & 0.252 & 0.219 & 0.493 & 0.235 & 0.227 \\
Growth (\%) & & -1.20 & -12.90 & 124.66 & -52.37 & 3.07 \\
NWC (x) & \multirow{2}{*}{0.0710} & 0.0470 & 0.0280 & 0.0161 & 0.0339 & 0.0252 \\
Growth (\%) & & -33.80 & -40.43 & -42.50 & 110.56 & -25.66 \\
CAPEX (x) & \multirow{2}{*}{0.099} & 0.073 & 0.087 & 0.089 & 0.076 & 0.049 \\
Growth (\%) & & -26.25 & 18.61 & 2.22 & -14.86 & -35.14 \\
SIZE (x) & \multirow{2}{*}{30.657} & 30.433 & 30.707 & 30.649 & 30.615 & 30.851 \\
Growth (\%) & & 0.73 & 0.90 & -0.19 & -0.11 & 0.77 \\
IOS (x) & \multirow{2}{*}{2.608} & 2.775 & 2.592 & 3.487 & 3.227 & 3.297 \\
Growth (\%) & & 2.18 & -7.46 & 34.51 & -6.57 & 6.37 \\
DPR (x) & \multirow{2}{*}{0.402} & 0.507 & 0.439 & 0.397 & 0.455 & 0.514 \\
Growth (\%) & & 20.92 & -13.49 & -9.48 & 14.54 & 12.89 \\
\hline Reference: Secondary data, Processed (2018) & & & &
\end{tabular}

Previous studies examined the effect of leverage on cash holding also found inconsistent findings. The research of Ogundipe et al (2012) showed leverage had a positive effect on cash holding, while Rizwan and Javeed (2011) and Belghitar and Khan (2013) showed leverage had negative effect on cash holding, and Kim et al (2011) study showed leverage had no significant effect on cash holding.

Inconsistent results also found in studies examined the effect of capital expenditure on cash holding. The research of $\mathrm{Wu}$ et al (2016) showed capital expenditure had a positive effect on cash holding, while Bates et al (2009) and Belghitar and Khan (2013) showed profitability had negative effect on cash holding, and Khan and Tanver (2016) study showed capital expenditure had no significant effect on cash holding.

Those inconsistent results of the effect of profitability, leverage, and capital expenditure on cash holding makes re-research is a necessary. The difference of this study compared to the previous research is laid within the use of dividend policy variables as moderating variables which moderate the effect of profitability, leverage, and capital expenditure on cash holding.

Based on the inconsistency of research results on factors that affect cash holding and the existence of business phenomena that show inconsistencies in the fluctuation data (in increase and a decrease) in cash holding variables and other variables, therefore the the purpose of this study are: 1) analyze and provide empirical evidence of the effect of profitability on cash holding; 2) analyze and provide empirical evidence of the influence of leverage on cash holding; 3 ) analyze and provide empirical evidence of the influence of capital expenditure on cash holding; 4) analyze and provide empirical evidence of the influence of liquid asset substitute on cash holding; 5) analyze and provide empirical evidence of the effect of investment opportunity set (IOS) on cash holding; 6) analyze and provide empirical evidence of the influence of company size on cash holding; 7) analyzing and giving empirical evidence dividend policy moderates the effect of profitability on cash holding; 8) analyzing and giving empirical evidence dividend policy moderates the effect of leverage on cash holding; and 9) analyzing and giving empirical evidence dividend policy moderates the influence of capital expenditure on cash holding.

\section{LITERATURE REVIEW AND HYPOTHESES DEVELOPMENT}

\section{Trade off theory}

According to trade off theory (Miller \& Orr, 1966), a company need to consider the additional benefits and costs gained by cash holding. Additional benefits from cash holding activities described Keynes (1936) was about the transaction motive related to the funding of routine transactions and company operations. Furthermore, cash holding activities were required to address a higher opportunity costs due to low cash holding (Tahir et al., 2016). 
A vigilant motive emphasized the possibility of overcoming high costs of using external funds to finance investments; therefore, a company needed to hold cash with sufficient or optimal amount. Speculation motive was related to the possibility of companies financing unexpected needs; large cash holdings would make the company able to avoid financial difficulties (Tahir et al., 2016).

Additional costs incurred due to cash holding would increase the cost of agency (Jensen, 1986). A company with very large amounts of cash did not need access to capital markets. Therefore the said company could not be closely monitored by regulatory and corporate stakeholders (Tahir et al, 2016). As a result, managers would prioritize their personal interests above the interests of the owners of the company. This would lead to the company's performance becoming not optimal because of the opportunist attitude from the corporate managers.

\section{Pecking order theory}

Pecking Order Theory (Myers \& Majluf, 1984) suggested that a company had a sequence in making funding decisions. First, companies should opt to use funds from internal companies. Second, the company should make adjustments to the amount of dividend payouts in the event of financial difficulties. The company would choose to sell its current assets at first. However, if that alternative was not sufficient, then the use of debt would become the next alternative until the sale of shares became the last funding option if the required funds were very large in number.

This funding sequence came from information asymmetric theory and a manager must do well to minimize agency costs that arose from these funding problems. Manager is more aware of the condition of the company and has more knowledge in which investment is profitable for the company. Moreover, he or she is assumed to have the same goals as shareholdersso that he or she will seek to issue shares at the highest or maximum price. A capital market investor who fully understands this issue will demand a higher premium because of a higher risk due to information asymmetry. As a result, funding using stock equity became more expensive (Tahir, et al., 2016). For that reason, the company should choose to use debt at first.

\section{Agency theory}

The agency theory (Jensen, 2007) has the main notion that a shareholder acted as a principal authorized power to manager as an agent to organize firms in order to prospering the shareholders. Problems occurred because of a conflict of interest; that is, managers utilize shareholders' confidence for self-profitable activities. Company-owned cash often led to conflicts between manager and shareholders, as managers are often inefficient in cash usage because they are used to finance low-return investments, but profitable for the manager himself.

The manager preferred to save a lot of cash to increase control over the company's assets in order to gain advantage for his own (Tahir et al., 2016). A company with strong affiliations with banks preferred to keep a little cash (Ferreira \& Viela, 2004). This action supported the existence of agency theory because manager with his authority had the ability to control the investment and financial decisions of the company. The use of debt could also reduce the conflicts of interest due to the company's cash (Jensen, 1986). Debt payments served as a force to discipline management's actions; but in turn, the ability of the management to collect cash will be reduced due to increasing debt.

\section{The bird in the hand theory}

This theory was developed by Lintner (1962) which essentially implied that the dividend policy would increase the value of the company. This theory was based on the notion that investors tend to avoid risks and opted to earn current dividends if compared to receiving future dividends despite bigger dividends promised in the future. Dividend payouts were considered capable of reducing the uncertainty of stock investments by investors. The paid dividend had a higher certainty or had a lower risk compared to the uncertainty capital gain obtained from the increasing prices in stocks. Therefore, the company needs to target a dividend payout ratio on a certain amount in order to create maximum corporate value.

\section{Profitability and cash holding}

Pecking order theory (Myers \& Majluf, 1984) stated that the company's funding sequence starting from the use of profits was withheld as a source of funding. A company's high 
profitability showed that the company had a good performance. The earned profits would be accumulated with previous earnings that were deposited by the company in retained earnings. Therefore, the greater profitability the company had, the retained earnings would also increase. With the increase of the retained earnings, the company could save more cash to be used to fund the company's activities. Several previous studies (Ogundipe et al., 2012; Naoki., 2012, Al-Najjar, 2013; Kariukii et al, 2016) also showed that profitability had a positive effect on cash holding.

\section{H1: Profitability positively affects cash holding}

\section{Leverage and cash holding}

Agency theory (Jensen, 2007) suggested that corporate managers tended to be opportunistic and thus use cash for unprofitable investments. As a result, the excess cash was used for things that were not efficient - therefore, necessary control was needed so that managers could invest optimally. One of many controls that can be done is to increase debt, because with the existence of debt, managers become more disciplined in managing cash - as cash is used to pay corporate liabilities. However, within a certain time, the company's cash will decrease due to the high amount of the company's debt so that more debt will lower cash holding. Some previous studies (Rizwan and Javeed, 2011; Lian et al, 2011; Belghitar and Khan, 2013; Mesfin, 2016; Al-Najjar and Clark, 2017) showed that Leverage negatively affected cash holding.

\section{H2: Leverage negatively affects cash holding}

\section{Capital expenditure and cash holding}

Pecking order theory (Myers, 1984) has the notion that if the company's funding requirements were not able to close with retained earnings, then the company was advised to use debt as an alternative funding. Company with large fixed assets would find it easier to get debt because of the debt guarantees owned by the company. If the company could get debt easily, it was not necessary to save a lot of cash because its need of funding could be completed with debt. Therefore, cash owned could be invested for other things. That was why the more the company's capital expenditure, there would be less cash that it needed to possess. Several previous studies (Bates et al., 2009; Rizwan \& Javeed, 2011; Kim et al., 2011; Wassiuzzaman, 2014) showed that capital expenditure negatively affected cash holding.

\section{H3: Capital expenditure negatively affects cash holding}

\section{Liquid asset substitute and cash holding}

Keynes (1936) stated that one motive for holding cash was because of the transaction motive. The company's cash was used for financing activities or public transactions that were often done by the company. If the company's cash was sufficient to finance the company's activities, then the company's condition would be more stable. Therefore, as described by Miller and Orr in 1966, it became an additional benefit for the company. If the company's cash was insufficient, then other current assets might be used to meet its funding. Large working capital allowed a company to have less cash because the current assets component in working capital had enough liquid to be used to fund the company's activities. Some previous studies (Kim et al., 2011: Wassiuzzaman., 2014; Nadia, 2016; Wu et al., 2016) showed liquid asset substitute negatively affected cash holding.

H4: Liquid asset substitute negatively affects cash holding

\section{The effect of investment opportunity set and cash holding}

The agency theory (Jensen, 1986) suggested that managers often made wastage of the company's cash for their own benefit. Companies with a set of bad investment opportunities had a tendency to store large amounts of cash. This was caused because the managers' opportunist attitude used cash to finance projects that were not worth the investment for their own personal gain. Several previous studies (Ferreira \& Viella, 2003; Gill \& Shah, 2012; Islam, 2012) also suggested that investment opportunity set affected cash holding negatively.

H5: Investment opportunity set negatively affects cash holding 


\section{Company size and cash holding}

Larger companies had easier way to finance their business activities. This could be possible because large companies have ability in economic scale that enabled them to do business more efficiently. As a result, these companies would only need less cash because they were able to utilize its economies of scale in accorandce with economies of scale theory (Miller \& Orr, 1966). Also, these large companies were also able to get external funding more easily. Several previous studies (Drobetz \& Gruningen, 2007; Islam, 2012; Nadia, 2016; Wu et al., 2016) showed that company size negatively affected Cash Holding.

H6: Company size negatively affects cash holding

\section{The moderating role of dividend policy in the relationship between profitability, leverage, capital expenditure and cash holding}

Dividend policy is a policy to determine how much net profit is to be distributed to investors in the form of dividends. Bird in the hand theory (Lintner., 1962) stated that companies needed to divide up large amounts of dividends in order to increase the value of their companies as investors basically preferred dividends that provided certainty rather than an uncertain increase in stock prices. As a result, the company that divided large amounts of cash would lose a lot of cash and the amount of Cash Holding would be scant. Several previous studies (Bates et al., 2009 and Wu et al., 2016) showed that dividend policies have a negative effect on Cash Holding.
Pecking order theory (Myers \& Majluf, 1984) claimed that a company would use its internal cash at first to fund its business activities - therefore the company that could generate huge profits would save more cash. In funding its activities - this included in paying dividends to investors, the company would use its own internal cash. As a result, the amount of cash generated from the profitability of the company would be reduced as the internal cash was used to pay dividends to investors. However, even if the company's cash was reduced, this action would make investors more prosperous and happy, and would lead to a result where the value of the company got increased.

The agency theory (Jensen, 1986) stated that a manager tended to be opportunistic; so a necessary control was needed to keep the manager from wasting the company's cash. The control mechanism that Jensen meant was with the use of Leverage and dividend payouts. By using both ways, the manager would be more controlled in using the company's cash, because the cash held first used to pay the debt and interest; and would be distributed for the prosperity of investors in the form of dividends. Therefore with the policy of dividend payouts, it would further strengthen the negative effect of debt towards cash holding owned by the company. When the amount of cash owned by the company was not excessive, it could automatically be a mechanism for disciplining corporate managers in managing the existing cash.

Jani et al (2004) by using pecking order theory (Myers \& Majluf, 1984), stated that a company with multiple capital expenditures or investments would collect substantial cash to meet this objective which was related to the expenditure on fixed assets of the company.

Table 2.

Comparison Beetween the Stocks Index of LQ 45 and Shares in IDX

\begin{tabular}{|c|c|c|c|c|c|c|}
\hline Market Capitalization (trillion) & 2011 & 2012 & 2013 & 2014 & 2015 & 2016 \\
\hline The stocks in LQ 45 & 2332.7 & 2552.3 & 2539.9 & 3337.4 & 2953.1 & 3796.3 \\
\hline Total shares in IDX & 3537.3 & 4127 & 4219 & 4774.3 & 4872.7 & 5753.6 \\
\hline Market Capitalization stocks in LQ 45 (\%) & $65.9 \%$ & $61.8 \%$ & $60.2 \%$ & $69.9 \%$ & $60.6 \%$ & $66.0 \%$ \\
\hline Transaction Value (trillion) & 2011 & 2012 & 2013 & 2014 & 2015 & 2016 \\
\hline $\begin{array}{l}\text { The value of stocks transactions LQ } 45 \\
\text { Index }\end{array}$ & 899.5 & 766.1 & 914.3 & 894.9 & 933.6 & 1321 \\
\hline The value of stocks transactions in IDX & 1223.4 & 1116.1 & 1522.1 & 1453.4 & 1406.3 & 1844.6 \\
\hline $\begin{array}{l}\text { The value of stocks transactions LQ } 45 \\
\text { Index (\%) }\end{array}$ & $73.5 \%$ & $68.6 \%$ & $60.1 \%$ & $61.6 \%$ & $66.4 \%$ & $71.6 \%$ \\
\hline
\end{tabular}


Table 3.

Measurements

\begin{tabular}{|c|c|c|}
\hline Variable & Measurements & Reference \\
\hline $\begin{array}{l}\text { Cash } \\
\text { Holding } \\
(\mathrm{CH})\end{array}$ & $\begin{array}{l}\mathrm{CH}=\text { Cash and cash } \\
\text { equivalents / total assets }\end{array}$ & $\begin{array}{l}\text { Al-Najjar } \\
\text { and Clark } \\
(2017)\end{array}$ \\
\hline $\begin{array}{l}\text { Profitability } \\
\text { (ROE) }\end{array}$ & $\begin{array}{l}\mathrm{ROE}=\text { net income }(\mathrm{EAT}) / \\
\text { total equity }\end{array}$ & $\begin{array}{l}\text { Foster } \\
(1986)\end{array}$ \\
\hline $\begin{array}{l}\text { Leverage } \\
\text { (DAR) }\end{array}$ & $\begin{array}{l}\text { DAR = total amount of debt } \\
\text { / total assets }\end{array}$ & $\begin{array}{l}\text { Foster } \\
(1986)\end{array}$ \\
\hline $\begin{array}{l}\text { Liquid } \\
\text { Asset } \\
\text { Substitute } \\
\text { (NWC) }\end{array}$ & $\begin{array}{l}\text { NWC }=\text { (current assets- } \\
\text { current liabilities - cash and } \\
\text { cash equivalents) / total } \\
\text { assets }\end{array}$ & $\begin{array}{l}\text { Bates et } \\
\text { al. (2009) }\end{array}$ \\
\hline $\begin{array}{l}\text { Investment } \\
\text { Opportunity } \\
\text { Set (MBVA) }\end{array}$ & $\begin{array}{l}\text { MBVA }=[\text { Assets-equity }+ \\
\text { (outstanding share } x \text { closing } \\
\text { price)] / total assets }\end{array}$ & $\begin{array}{l}\text { Kim et al. } \\
(2009)\end{array}$ \\
\hline $\begin{array}{l}\text { Capital } \\
\text { Expenditures } \\
\text { (CAPEX) }\end{array}$ & $\begin{array}{l}\text { CAPEX }=[\text { fixed assets }(t)- \\
\text { depreciation expense }(t)- \\
\text { fixed assets }(t-1)] / \text { total } \\
\text { assets }\end{array}$ & $\begin{array}{l}\text { Bates et } \\
\text { al. (2009) }\end{array}$ \\
\hline $\begin{array}{l}\text { Firm } \\
\text { Size } \\
\text { (SIZE) }\end{array}$ & SIZE $=$ Ln Total assets & $\begin{array}{l}\text { Kim et al. } \\
(2011)\end{array}$ \\
\hline $\begin{array}{l}\text { Dividend } \\
\text { Policy (DPR) }\end{array}$ & $\begin{array}{l}\text { DPR = dividend per share / } \\
\text { earnings per share }\end{array}$ & $\begin{array}{l}\text { Foster } \\
(1986)\end{array}$ \\
\hline
\end{tabular}

Therefore, the company's internal cash that had been collected would be eroded to fund the acquisition of the company's fixed assets and the company would rely on debt as an alternative to funding other things aside from internal cash. This saying was in accorandce with the statement of Bates et al (2009) which claimed that if a company had a lot of fixed assets; it would increase its debt level because the fixed assets could be used as debt guarantees. In addition, the company who had paid dividends would also experience a decrease in the amount of cash owned (Al-Najjar, 2013). If the company made a lot of fixed assets, there would be less cash.

H7: The existence of a dividend policy moderates the effect of profitability on cash holding

H8: The existence of a dividend policy moderates the effect of leverage on cash holding
H9: The existence of a dividend policy moderates the influence of capital expenditure on cash holding

\section{METHODS}

This study used the population of companies listed on the LQ 45 Index during the period 2011-2016. Table 2 shows the reasons for choosing the LQ 45 Index as sample in this research. In 2016, the stock market capitalization in the LQ 45 Index reached $66 \%$ of the total market capitalization of the shares. The LQ 45 Index's share value in 2016 reached $71.6 \%$ of the total value of stock transactions on the IDX. Therefore, LQ 45 Indexes had become one of the favorite stocks for investors and was able to become the prime mover of Indonesia Composite Index (IDX). 
Table 4.

Results of Hypothesis Testing

\begin{tabular}{|c|c|c|c|c|c|c|}
\hline \multirow{2}{*}{ Indep Var } & \multicolumn{2}{|c|}{ Common effect } & \multicolumn{2}{|c|}{ Fixed effect } & \multicolumn{2}{|c|}{ Random effect } \\
\hline & Model 1 & Model 2 & Model 1 & Model 2 & Model 1 & Model 2 \\
\hline \multirow[t]{2}{*}{ ROE } & $0.414^{\star \star *}$ & $0.217^{* \star *}$ & $0.157^{\star *}$ & $0.093^{\star *}$ & $0.003^{* * *}$ & $0.0001^{* x}$ \\
\hline & 0.000 & 0.007 & 0.032 & 0.048 & 0.000 & 0.018 \\
\hline \multirow[t]{2}{*}{ DAR } & $-0.175^{\star *}$ & $-0.212^{* * *}$ & $-0.207^{\star \star *}$ & $-0.318^{\star * *}$ & $-0.163^{\star *}$ & $-0.255^{\star *}$ \\
\hline & 0.024 & 0.004 & 0.000 & 0.002 & 0.044 & 0.002 \\
\hline \multirow[t]{2}{*}{ CAPEX } & $-0.187^{* *}$ & $-0.421^{* *}$ & $-0.195^{\star}$ & $-0.223^{*}$ & $-0.215^{\star *}$ & $-0.263^{* *}$ \\
\hline & 0.036 & 0.016 & 0.054 & 0.085 & 0.026 & 0.033 \\
\hline \multirow[t]{2}{*}{ NWC } & -0.214 & -0.007 & 0.015 & -0.004 & 0.014 & -0.0004 \\
\hline & 0.831 & 0.864 & 0.241 & 0.885 & 0.278 & 0.839 \\
\hline \multirow[t]{2}{*}{ IOS } & -1.931 & -0.062 & -0.017 & -0.021 & -0.0005 & -0.004 \\
\hline & 0.156 & 0.329 & 0.345 & 0.205 & 0.142 & $0.363^{\star * *}$ \\
\hline \multirow[t]{2}{*}{ SIZE } & $-0.902^{*}$ & $-0.053^{*}$ & $-0.142^{*}$ & $-0.343^{*}$ & 0.0006 & -0.003 \\
\hline & 0.068 & 0.057 & 0.078 & 0.064 & 0.254 & 0.399 \\
\hline \multirow[t]{2}{*}{ DPR } & & $-0.067^{*}$ & & $-0.012^{* *}$ & & 0.015 \\
\hline & & 0.072 & & 0.035 & & 0.394 \\
\hline \multirow[t]{2}{*}{ ROE*DPR } & & -0.006 & & $-0.007^{\star}$ & & $-0.008^{*}$ \\
\hline & & 0.312 & & 0.087 & & 0.081 \\
\hline \multirow[t]{2}{*}{$\mathrm{DAR}^{*} \mathrm{DPR}$} & & $-0.008^{*}$ & & $-0.083^{* * *}$ & & $-0.09^{* * *}$ \\
\hline & & 0.084 & & 0.003 & & 0.003 \\
\hline \multirow[t]{2}{*}{ CAPEX*DPR } & & $-0.021^{* *}$ & & -0.004 & & $-0.011^{*}$ \\
\hline & & 0.038 & & 0.162 & & 0.09 \\
\hline Std error & 0.082 & 0.104 & 0.046 & 0.005 & 0.058 & 0.048 \\
\hline Adj $R$ & 0.207 & 0.142 & 0.751 & 0.823 & 0.267 & 0.321 \\
\hline F-test & $5.68^{\star \star *}$ & $3.76^{\star \star \star}$ & $15.03^{\star \star \star}$ & $12.54^{\star \star \star}$ & $7.52^{\star \star \star}$ & $5.86^{\star * \star}$ \\
\hline
\end{tabular}

Depend Variable : Cash Holding $(\mathrm{CH})$

${ }_{* \star *},{ }^{* *},{ }^{*}$ significant at $1 \%, 5 \%, 10 \%$

Purposive sampling method was used to determine the sample in this study. We managed to get 108 observations which had met the criteria for determining observation and the criteria of classical assumption in multiple regression tests. The data used is secondary data obtained from the company's financial statements and use panel data (Financial statements of several companies during the 2011-2016 period). Financial reports are obtained from IDX's official website.

As presented in Table 3, measurement of cash holding refer to Al-Najjar and Clark (2017), while profitability, dividend policy, and leverage refer to Foster (1986). Measurement developed by Bates et al. (2009) used as a proxy of liquid asset substitute and capital expenditures. To measure IOS and firm size, we use measurement developed by Kim et al. (2011).

Our study used two regression models. The first regression model was used to test the first until the sixth hypothesis. The second regression model was used to test the moderating role dividend policy in the seventh hypothesis. The models used in this study is developed as follows:

$$
\begin{aligned}
C H= & \beta 1 R O E+\beta 2 D A R+\beta 3 I O S+\beta 4 N W C+ \\
& \beta 5 C A P E X+\beta 6 S I Z E+e \text { (Model 1) } \\
C H= & \beta 1 R O E+\beta 2 D A R+\beta 3 I O S+\beta 4 N W C \\
& +\beta 5 C A P E X+\beta 6 \text { SIZE }+\beta 7 D P R+ \\
& \beta 8 R O E^{*} D P R+\beta 9 D A R^{*} D P R+ \\
& \beta 10 C A P E X^{*} D P R+e(\text { Model } 2)
\end{aligned}
$$

Where $\mathrm{CH}=$ cash holding, $\mathrm{ROE}=$ return on equity, $\mathrm{DAR}=$ debt to equity ratio, $\mathrm{IOS}=$ investment opportunity set, NWC = liquid asset substitute, CAPEX = capital expenditure, SIZE = company size, DPR = dividend payout ratio.

\section{RESULTS AND DISCUSSION}

Table 4 present descriptive statistics of the sample consisted of 108 observations which had met the requirements of classical assumption testing (normality testing, multicolinearity, heteroedasticity and autocorrelation). Then the data that had met the classical assumption test would be used as a sample for hypothesis testing. From table 4, it is known that the average value of $\mathrm{CH}$ is 0.162 . This means that the average amount of cash and cash equivalents of a sample company is $16.2 \%$ of total assets. 


\section{First equation model}

Fixed effect model is the best model for the first and second regression equation, which is shown from the significance of the chow test of 0,000 and also significant with hausmann test. The value of adjusted R2 in first model is 0.751 . It shows that Independent variable in first model are able to explain the cash holding value of $75.1 \%$, and the rest is explained by other variables outside the model. The value of F-test is 15.03 and significant at level $1 \%$. It shows that independent variables in the first model simultaneously affect the value of cash holding and it can be concluded that the first model has been decent (goodness of fit). We know that beta:

$$
\begin{aligned}
C H= & 0.157 R O E-0.207 D A R-0.195 C A P E X- \\
& 0.015 N W C-0.017 I O S-0.142 S I Z E
\end{aligned}
$$

\section{Second equation model}

The value of adjusted $R 2$ in second model is 0.823 . It shows that the variable ROE, DAR, CAPEX, IOS, NWC, SIZE, DPR, DPR ${ }^{\star} R O E$, $\mathrm{DPR}^{\star} \mathrm{DAR}$, and $\mathrm{DPR}^{\star} \mathrm{CAPEX}$ are able to explain the cash holding value of $82.3 \%$, and the test is explained by other variables outside the model. The value of F-test is 0.000 and significant at level $1 \%$. It shows that independent variables in second equation simultaneously affect the value of cash holding, and it can be concluded that the second model has been decent (goodness of fit). From the second model testing we know that beta value of standardized residual in this research is:

$$
\begin{aligned}
C H= & 0.093 R O E-0.318 D A R-0.223 C A P E X- \\
& 0.004 N W C-0.021 \text { IOS }-0.343 S I Z E- \\
& 0.012 D P R-0.007 D P R^{*} R O E-0.083 \\
& D P R^{*} D A R-0.004 D P R^{*} C A P E X
\end{aligned}
$$

\section{Discussion}

The best model in this study uses the fixed effect (Table 5-9), so the discussion of the hypothesis will use the results of the fixed effect test model in table 4. The Chow test results show a $p$-value of 0,000 (significant at $1 \%$ ) and the Hausmann test results show a pvalue of 0.04 (significant at the $5 \%$ level) so that fixed effect is the best model in the regression model of this study.

\begin{tabular}{|c|c|c|c|}
\hline \multicolumn{4}{|c|}{$\begin{array}{l}\text { Redundant Fixed Effects Tests } \\
\text { Equation: Untitled } \\
\text { Test cross-section fixed effects }\end{array}$} \\
\hline Effects Test & Statistic & d.f. & Prob. \\
\hline $\begin{array}{l}\text { Cross- } \\
\text { section F }\end{array}$ & 13.958076 & (17.84) & 0.0000 \\
\hline $\begin{array}{l}\text { Cross- } \\
\text { section Chi - } \\
\text { square }\end{array}$ & 144.884043 & 17 & 0.0000 \\
\hline
\end{tabular}

Table 5.

Descriptive Statistics

\begin{tabular}{llllll}
\hline Variable & $\mathrm{N}$ & Min & Max & Mean & $\begin{array}{l}\text { Std. } \\
\text { Dev. }\end{array}$ \\
\hline $\mathrm{CH}$ & 108 & 0.01 & 0.59 & 0.17 & 0.11 \\
ROE & 108 & 1.24 & 52.43 & 17.3 & 10.52 \\
DAR & 108 & 0.13 & 0.83 & 0.39 & 0.16 \\
CAPEX & 108 & 0.002 & 0.51 & 0.08 & 0.07 \\
NWC & 108 & -0.16 & 5.93 & 0.38 & 0.99 \\
IOS & 108 & 0.01 & 32.84 & 5.67 & 9.51 \\
SIZE & 108 & -0.19 & 33.24 & 27.17 & 10.12 \\
DPR & 108 & 6.54 & 87.86 & 41.7 & 17.55 \\
\hline Source:
\end{tabular}

\begin{tabular}{|c|c|c|c|}
\hline \multicolumn{4}{|c|}{$\begin{array}{l}\text { Correlated Random Effects-Hausman Test } \\
\text { Equation: Untitled } \\
\text { Test cross-section random effects }\end{array}$} \\
\hline $\begin{array}{l}\text { Test } \\
\text { Summary }\end{array}$ & $\begin{array}{l}\text { Chi-Sq. } \\
\text { Statistic }\end{array}$ & $\begin{array}{l}\text { Chi-Sq. } \\
\text { d.f. }\end{array}$ & Prob. \\
\hline $\begin{array}{l}\text { Cross- } \\
\text { section } \\
\text { random }\end{array}$ & 12.700523 & $(17.84)$ & 0.0480 \\
\hline
\end{tabular}

Table 6.

Chow Test (First Regression Model)

Table 7.

Hausman Test (First Regression Model)

Table 8.

Chow Test (Second Regression Model)

Redundant Fixed Effects Tests
Equation: Untitled
\begin{tabular}{llll} 
Test cross-section fixed effects & \\
\hline Effects Test & Statistic & d.f. & Prob. \\
\hline $\begin{array}{l}\text { Cross- } \\
\text { section F }\end{array}$ & 13.971893 & $(17.80)$ & 0.0000 \\
$\begin{array}{l}\text { Cross- } \\
\text { section Chi - } \\
\text { square }\end{array}$ & 148.880272 & 17 & 0.0000 \\
\hline
\end{tabular}


Table 9.

Hausman Test (Second Regression Model)

\begin{tabular}{|c|c|c|c|}
\hline $\begin{array}{l}\text { Correlated F } \\
\text { Equation: U } \\
\text { Test cross-s }\end{array}$ & $\begin{array}{l}\text { dom Effects } \\
\text { led } \\
\text { tion random }\end{array}$ & $\begin{array}{l}\text { lausma } \\
\text { ffects }\end{array}$ & \\
\hline $\begin{array}{l}\text { Test } \\
\text { Summary }\end{array}$ & $\begin{array}{l}\text { Chi-Sq. } \\
\text { Statistic }\end{array}$ & $\begin{array}{l}\text { Chi-Sq. } \\
\text { d.f. }\end{array}$ & Prob. \\
\hline $\begin{array}{l}\text { Cross- } \\
\text { section } \\
\text { random }\end{array}$ & 20.070490 & 10 & 0.0286 \\
\hline
\end{tabular}

Table 4 shows that profitability (ROE) has a positive effect on cash holding and significance at level $5 \%$. This finding in line with pecking order theory (Myers, 1984); which stated that the company would use retained earnings as the first funding alternative. Therefore when the company has a large profit, then the profit will be saved and accumulated into retained earnings so that the cash will also be increased; thus, hypothesis 1 is supported.

Leverage (DAR) has a negative effect on cash holding and significance at level $1 \%$. This is in accordance with agency theory (Jensen, 1986); which claimed that debt could be a control mechanism against the opportunistic behavior of managers in managing cash. With the existence of debt, the company has an obligation to pay interest expense and loan principal so that the cash owned by the company will be reduced to pay off the said obligation. We can conclude that hypothesis 2 in this study is supported.

Capital expenditure (CAPEX) has negative effect upon Cash Holding and significance at level $10 \%$. This result is in accordance with Pecking Order Theory (Myers, 1984); which stated that if the company's internal funds were insufficient, debt could be used as the second funding source. The theory further claimed that a company with large fixed assets would find it easier to obtain debt because their fixed assets could be used as collateral for the company's debts. As a result, the company that bought a lot of fixed assets did not need to have a lot of cash with them because they could use debt as a source of funding. We can conclude that hypothesis 3 in this study is supported.

Liquid asset substitute (NWC) has not significant effect on cash holding. This result is not accordance with trade off Theory (Miller \& Orr, 1966); which suggested that a company needed to weigh in the benefits and costs of storing cash. One of the benefits of storing cash related transaction motive was that the cash itself was used to fund general transactions of the company. If the company had current assets other than large cash, they did not need to save too much cash because the current assets other than cash could easily be converted into cash that could be used by the company. We can conclude that hypothesis 4 in this study is not supported. The most plausible reason these finding is because companies with large liquid asset substitutes (account receivables and inventories) do not necessarily have a little cash because the company could have cash from debt, sales of fixed assets or because of a low dividend payout ratio. In addition, the standard deviation value of the NWC variable is very high at 0.99 so that it exceeds the average value of 0.38 which indicates the NWC has no significant effect on cash holding

Investment opportunity set has not significant effect on cash holding. This result is not in line with agency theory (Jensen, 1986); which stated that corporate managers tend to use corporate cash for waste; so that when they saw a set of bad investment opportunities, they tend to keep large sums of cash. This was because managers would use the funds for inappropriate investments that only benefit them personally without increasing the value of the company. We can conclude that hypothesis 5 in this study is not supported. IOS is an external variable whose value is determined by the market through the company's stock price, this is the reason the fifth hypothesis is rejected because the company's cash determination policy is not determined by the stock market conditions that have high fluctuations

Firm size has a negative effect on cash holding and significance at level $10 \%$. This is in accordance with economies of scale theory (Miller \& Orr, 1966); which stated that large companies had economies of scale ability that made their operations became more efficient. As a result, large companies did not need to save a lot of cash because they were able to run business activities more efficiently; and the existing cash could be used for other profitable investments.We can conclude that hypothesis 6 in this study is supported.

In this study, dividend policy can be a moderating variable which role gets weakened the positive effect of profitability on cash holding. This can be seen from the value of the initial regression coefficient of ROE to cash holding of 0.093 . However, 
when ROE is interacted with the dividend policy, the regression coefficient value drops to -0.007 , the total effect is $0.01(0.093+0.007)$. The existence of dividend policy can be reduce the positive effect of ROE from 0.093 to -0.007 .

Dividend policy also can be a moderating variable which role gets strenghten the negative effect of Leverage on cash holding. Companies that have a lot of debt will have less cash, the amount of cash held will decrease when the company decides to distribute dividends to shareholders The coefficient regretion of leverage on cash holding is -0.318 and the existence of dividend policy as moderating variable can change the coefficient regression to -0.083 , so the total effect is $-0.401(-0.212-0.083)$.

However, dividend policy can't be a moderating variable in the correlation of capital expenditure and cash holding. It can be seen the significance of $t$ variable CAPEX ${ }^{*} D P R$ in fixed effect model which is the interaction of capital expenditure variable and dividend policy of 0.216 is not significant. Purchasing fixed assets does not have to use large amounts of company money, companies can borrow banks or use funding from the capital market to meet their funding. In addition, the company could only rent fixed assets to fulfill its operations so that the costs incurred would be less.

\section{CONCLUSION}

This study examined the factors that determined the companies' cash holding listed in LQ 45 Index during 2011-2016 by adding a moderation variable of dividend policy as the novelty of the study. The results showed that dividend policy could be a moderating variable that weakened the positive influence of profitability on cash holding and strengthened the negative impact of leverage on cash holding.

The findings of this study further strengthen trade off theory, pecking order theory and agency theory in explaining the factors that could affect cash holding. For managers to earn a substantial cash holding rate, companies should strive to generate maximum net profits because the cash earned from the company's earnings will be retained for internal company. This is because retained earnings that can be used to fund the main business activity of the company as suggested by pecking order theory. If the companies' cash is in excessive amounts, then it is prone to be abused by managers for their own interests. Therefore, the amount of existing cash needs to be reduced by using the mechanism of debt or dividend payments because both debt and dividends are statistically proven to be able to reduce the amount of cash significantly.

This research has several limitations such as: The sample of this study. The researcher used LQ 45 index which consisted of many sectors; while for each industry, sector may have different levels of cash holding because there are several sectors whose business activities are dependent on the exchange rate, commodity prices and others. Furthermore, this study only used financial data and did not include the variable of good corporate governance as the determining factor of cash holding; while cash holding policy is also made and determined by directors, independent commissioners, and risk management committees.

Based on the limitations of the research described above, the upcoming research agenda is for researchers to use more specific sectors. For instance, mining companies, agriculture, infrastructure, manufacturing and other companies because each sector has its own peculiarities in determining the amount of its cash holding and includes the variable good corporate governance such as managerial ownership, the number of independent commissioners, risk management committee and others.

\section{REFERENCES}

Al-Najjar, B. (2013). The financial determinants of corporate cash holdings: Evidence from some emerging markets. International Business Review, 22(1), 77-88. https://doi.org/10.1016/j.ibusrev.2012.02. 004

Al-Najjar, B., \& Clark, E. (2017). Corporate governance and cash holdings in MENA: Evidence from internal and external governance practices. Research in International Business and Finance, 39, $1-12$.

https://doi.org/10.1016/j.ribaf.2016.07.030

Belghitar, Y., \& Khan, J. (2013). Governance mechanisms, investment opportunity set and SMEs cash holdings. Small Business Economics, 40 (1), 59-72. https://doi.org/10.1007/s11187-011-9366z

Drobetz, W., \& Grüninger, M. C. (2007). Corporate cash holdings: Evidence from 
Switzerland. Financial Markets and Portfolio Management, 21(3), 293-324. https://doi.org/10.1007/s11408-007-00528

Ferreira,M.A., \& Vilela,A.S. (2003). Why Do Firms Hold So Much Cash:Evidence From EMU Countries, European Financial Management, 10, 295-319. http://dx.doi.org/10.2139/ssrn.614002

Foster, G. (1986). Financial statement analysis, New Jersey: Prentice-Hall Englewood Cliffs

Gill, A., \& Shah, C. (2012). Determinants of corporate cash holdings: Evidence from Canada. International Journal of Economics and Finance, 4(1), 70-79.

Jani, E., Hoesli, M., \& Bender, A. (2011). Corporate Cash Holdings and Agency Conflicts. SSRN Electronic Journal, 1-30. https://doi.org/10.2139/ssrn.563863

Jensen, M. C. (1986). Agency costs of free cash flow, corporate finance, and takeovers. The American economic review, 76(2), 323-329.

Jensen, M. C. (2007). Agency Costs of Free Cash Flow , Corporate Finance, and Takeovers Michael C. Jensen The American Economic Review, Vol . 76 , No. 2 , Papers and Proceedings of the Ninety-Eighth Annual Meeting of the American Economic Association . (May, 1986 ), pp . 76(2), 323-329.

Kariuki, S. N., Namusonge, G. S., \& Orwa, G. O. (2015). Determinants of corporate cash holdings: evidence from private manufacturing firms in Kenya. International Journal of Advanced Research in Management and Social Sciences, 4(6), 15-33.

Keynes, John M. (1936). The General Theory of Employment, Interest and Money (pp. 170-174) , New York: Harcout Brace Jovanovich

Kim, J., Kim, H., \& Woods, D. (2011). Determinants of corporate cash-holding levels: An empirical examination of the restaurant industry. International Journal of Hospitality Management, 30(3), 568574.

https://doi.org/10.1016/j.jhm.2010.10.004
Lian,Y., Sepheri,M., Foley,M. (2009). in T Imes of F Inancial C Risis. European Business Organization Law Review, 1(71002056), 1-8. https://doi.org/10.1093/ajae/aaq031

Lintner, J. (1962) Dividends, Earnings, Leverage, Stock Prices and the Supply of Capital to Corporations. The Review of Economics and Statistics, 44, 243-269. http://dx.doi.org/10.2307/1927792

Mesfin, E. A. (2016). The Factors Affecting Cash Holding Decisions Of Manufacturing Share Companies In Ethiopia. International Journal of Advanced Research in Management and Social Sciences, 5(3), 48-67.

Miller, M. H., Orr, D. (1966). A Model of the Demand for Money by Firms. The Quarterly Journal of Economics. 80(3), 413-435

Myers, S. C., \& Majluf, N. S. (1984). Corporate financing and investment decisions when firms have information that investors do not have. Journal of Financial Economics, 13(2), 187-221. https://doi.org/10.1016/0304405X(84)90023-0

Naoki, S. (2012). Firms' Cash Holdings and Performance: Evidence from Japanese corporate finance.

Ogundipe, S. E., Salawu, R. O., \& Ogundipe, L. O. (2012). The Determinants of Corporate Cash Holdings in Nigeria: Evidence from General Method of Moments (GMM). International Journal of Social, Behavioral, Educational, Economic, Businessand Industrial Engineering, 6(1), 152-158. Retrieved from scholar.waset.org/1999.1010/4420

Rizwan, M., Javed, T (2011). Determinants of corporate cash holdings : Evidence From Pakistani Corporate sector. Journal of Economics, Management and financial Markets 6 (1), 344-358

Yang, X., Han, L., Li, W., Yin, X., \& Tian, L. (2017). Monetary policy, cash holding and corporate investment: Evidence from China. China Economic Review, 46(September), 110-122. https://doi.org/10.1016/j.chieco.2017.09.0 01 